\title{
Jakob Linzbach on his life and work ${ }^{1}$
}

\author{
Sébastien Moret \\ Department of Slavic and South Asian Studies \\ Anthropole - 4090.1 \\ University of Lausanne, Switzerland \\ e-mail: sebastien.moret@unil.ch
}

\begin{abstract}
The Estonian scholar Jakob Linzbach is primarily known for having published, in 1916, a Russian-language book with the title The Principles of Philosophical Language: An Attempt at Exact Linguistics. In this book, and in his other published and unpublished works, he aimed at creating a universal written language in which mathematics and images would mix. Linzbach's ideas have raised awareness among people from different (scholarly) fields - semiotics, interlinguistics, philosophy, cinema theory, informatics, etc. However, not much has been published about Linzbach's life. In one of his manuscripts kept in Tartu, there is a chapter that can be considered an autobiography and that provided, in the pencil of Linzbach himself, information about his life and work. This text is edited, translated into English and commented here for the first time.
\end{abstract}

Keywords: history of linguistics; history of semiotics

The Estonian Jakob Linzbach or Lintsbach (1874-1953; in Russian: Яков Иванович Линибах) is primarily known for having published in 1916, the same year in which Saussure's Cours de linguistique générale was published (on Linzbach and Saussure and their conceptions of linguistics, see Moret 2018), a book in Russian entitled The Principles of Philosophical Language: An Attempt at Exact Linguistics (Lintsbah 2009[1916]). With this book, and with his other published texts (e.g. Linzbach 1921 or 1931) or unpublished manuscripts kept at the library of the University of Tartu in Estonia (see Dulichenko 2005: 122ss), Linzbach aimed at

\footnotetext{
1 This article is a part of the research project "Sémiotique, sémantique et interlinguistique: autour des idées de Jakob Linzbach (1874-1953)" supported by the Swiss National Science Foundation (subsidy n ${ }^{\circ}$ PP2LAP1-158676). In 2015-2016, the author worked as a postdoctoral fellow at the Department of Semiotics, University of Tartu, Estonia.
} 
creating a philosophical, universal language that could be used and understood by everyone. He intended to continue the research initiated by Leibniz (1646-1716) at his time (Lintsbah 2009 [1916]: vi).

Linzbach's universal language was meant to be a pasigraphy (Dulichenko 1990: 206; Janton 1993: 4), i.e. a written one that would mix mathematics and images. As Yuri Tsivian (2014: 88) sums it up, Linzbach wanted "to go from speaking to writing and from grammar to math". In Linzbach's own words, he "created a figurative common mathematics in which we apply not only numbers, but also all other logical representations by indicating them with ideographic symbols whose purpose is to replace the words of ordinary language" (Linzbach 1931: 2). This will lead to a "language of pure mathematics" (Lintsbah 2009[1916]: xi), which he described the following way:

the new language is a language with no lexicon and no grammar. Because the lexicon and the grammar are replaced by the rules of mathematics. Geometry is used here as etymology, and algebra as syntax: more precisely, the letters are replaced by numbers [...]. (Lintsbah 2009[1916]: viii)

Still, Linzbach's project of a universal language was more than a system of writing devised to deliver information through images and mathematical symbols:

In his vision, the writing of the future will include a variety of things: pictures, formulae, body language, the language of music and color, glossolalia, geometrical graphs, and, not least, a kind of schematized animated cinema which Lintsbach variously called 'living schemes,' 'the cinematographs of icons,' and the 'manual language of the mind'. (Tsivian 2014: 88-92)

This is probably why Linzbach's book raised awareness among people from different (scholarly) fields (as did Saussure's) - unlike to what Isaak Revzin (19231974) thought, The Principles of Philosophical Language did not remain unnoticed (Revzin 1977: 41). According to Yury Tsivian (1998: 122), it is the world of Soviet cinema that, apparently first, took an interest in Linzbach's ideas, republishing, in 1918, in the magazine Mir ekrana [The World of the Screen] the chapter that Linzbach had devoted to cinema (Lintsbah 2009[1916]: 68-75). Tsivian (1998: 122) also mentions the presence of Linzbach in a 1923 article by the filmmaker Ippolit Sokolov (1902-1974)2. At the end of the 1910s a criticism of Linzbach's ideas can also be found in a text by Russian Orthodox theologian and philosopher Pavel Florenskij (1882-1937) who reproached Linzbach (among other things;

2 Tsivian indicates that this is the article "Skrizhal' veka" ["The tablet of the century"] published in the first issue of the constructivist journal Kinofot in 1923. 
Florenskij's criticism of Linzbach's project would deserve a special study) for his mechanical conception of language:

\begin{abstract}
On the contrary, Linzbach simply does not love the language, does not feel his connection with it, lives in it not as in his body, but as in a hired hotel room, and therefore, he naturally is concerned about the most rational furniture layout [obmeblirovka] of this room. The very thought of the organic in the language is alien to him: he recognizes everything as made and not as born, and the language is not an exception [ $i$ yazik otsyuda ne isklyuchaetsya]. What is dear to Linzbach is not language itself, but the services of the language [Lintsbahu ne dorog yazyk, dorogi uslugi yazyka]; [...] (Florenskij 1988[1918]: 117)
\end{abstract}

Obviously, Linzbach's book was also noticed by the adepts of artificial languages Linzbach was also a member and, for a while, even president of the Kosmoglott Society for International Language in Tallinn (see Kuznetsov 2016) and, at the beginning of the 1930s, the Soviet esperantist and theoretician Ėrnest Drezen (1892-1937) mentioned Linzbach's "very serious", but "as yet uncompleted" work (Drezen 1991[1931]: 189). Recently, a book on artificial languages dedicated several pages to Linzbach's project (Piperski 2017: 65-71), which was also used for a question for the 2003 International Linguistics Olympiad ${ }^{3}$.

Nowadays, Linzbach is also known among semioticians and considered as a pioneer of semiotics (see, e.g., Ivanov 1977; Kull et al. 2005; Romeo 1979; Tsivian 1998 and 2014). The semiotic "life" of Linzbach's book began in 1965, when Soviet linguist and semiotician Isaak Revzin rediscovered The Principles of Philosophical Language and published a Russian-language review (Revzin 2009[1965]) of it in Trudy po znakovym sistemam [Sign Systems Studies]. This article paved the way to the discovery of what Luigi Romeo (1979: 371) called the "Estonian current" in the history of semiotics, and Linzbach's name began to be mentioned by authors such as Julia Kristeva (1967: 178-179), or Umberto Eco (1932-2016) (Eco 1976: 31, Footnote 3, referring to Kristeva 1967). Yet this does not mean, though, that Linzbach has become a key figure of semiotics; e.g. he is not mentioned in Nöth's Handbook of Semiotics (Nöth 1995) or in the history of the Tartu School of Semiotics by Waldstein (2000).

It should be added that Linzbach is also considered as "a very strong forerunner of the modern information theory" (Lumiste, Võhandu 2007) and one of the scholars constituting the "archive" of the "local episteme" called "Estonian theory" (Tamm, Kull 2016).

As we can see, Linzbach's name is "often mentioned in the [scientific] literature"

3 See https://en.wikipedia.org/wiki/Jacob_Linzbach (viewed 1 February, 2019). 
(Kruus 1988: 31), whether it be about history of interlinguistics or semiotics (Pocheptsov 1998). Yet what we know about Linzbach himself is still lacking ${ }^{4}$.

At the end of his review of The Principles of Philosophical Language, Revzin dedicated a few words to Linzbach and his personality and praised him as "remarkable" and "undoubtedly" (Revzin 2009[1965]: 230) belonging to the people Linzbach himself had described as "brilliant [genial'nyj]" and endowed with the "capacity for intuition" in his book (Lintsbah 2009 [1916]: 208). Since 1965, the history and biography of Linzbach have been better known, in particular thanks to the work conducted by Rein Kruus (1957-1992) in different Soviet and Estonian archives (see Kruus 1988). Kruus, however, wrote in Russian and what is available so far in English is not much ${ }^{5}$ : in an article by Tsivian one can read, for example, that Linzbach was "[e]ducated as a railway technician, draftsman, and stenographer" and owned a "drafting shop in Petrograd" (Tsivian 1998: 121).

In one of Linzbach's manuscripts kept in the archives of the library of the University of Tartu in Estonia, there is a chapter that can be considered an autobiography and that provides, in Linzbach's own pencil, information on his life and work. This autobiographical text written in Russian will be presented and published here in an English translation with notes and comments. Of course, the knowledge of someone's life is not necessary to consider and analyse their work, but, nevertheless, the edition and publication of this text by Linzbach about himself written a couple of years before his death may broaden the understanding of the universe he lived in and provide factual information about his life.

From an archival point of view, the publication of and the comments related to this autobiography by Linzbach will also permit to organize chronologically and to contextualize most of the documents kept in Linzbach's fond in Tartu.

4 Until recently, no picture of Linzbach seemed to be available online. Now an image can be found at https://medium.com/@osowski/яков-линцбах-1874-1953-с43c9c113488 (viewed on 1 February 2019).

5 We will not consider here what has been written about Linzbach in Estonian. As far as we know, a biographical part about Linzbach is available in Lumiste, Võhandu 2007. 


\section{Linzbach's “History of my research" (1951-1952) - Presentation $^{6}$}

The autobiographical chapter is entitled "History of my research" ["Istoriya moego issledovaniya"] and is the nineteenth and last part (pp. 416-436) of a quite voluminous (439 pages) manuscript work whose title is Universal'naya nauka I. Universal'nyj yazyk [Universal Science I. Universal Language] (Lintsbah 19511952). This text is kept in Linzbach's fond ${ }^{7}$ in the archives of the library of Tartu University (fond 101, item 10). The manuscript consists of a doubly perforated cardboard binding; the pages, handwritten in pencil, are secured by a string looped through the holes in cardboard and the sheets. Throughout the entire manuscript and also in this special chapter, corrections and additions can be seen, added, probably by Linzbach himself, in another pencil; these additions/corrections have been taken into account, and are indicated between \{\} only in the Russian original text. On the other hand, words and phrases that have been crossed out in the original document have also been omitted here.

In the Russian original text, all words or signs enclosed in square brackets are either comments, additions or corrections from the author of these lines, and the numbers in square brackets indicate the pages of the original document; in the English translation, the pages of the original document are not indicated. In both the reprint of the Russian original and English translation, the titles of books indicated by Linzbach have been formatted using the journal's editorial style (titles in italics, etc.), which was not the case in the hand-written original. In this case, the modifications are not mentioned.

6 The author would like to thank Yuri Kleiner (St. Petersburg State University), Aleksandr Dulichenko (University of Tartu), Oleg Ershov (St. Petersburg), Monette Bouberguig (Lausanne) and the editors of Sign Systems Studies for their precious help and advice in editing and translating this text.

7 The description of Linzbach's archival fond in Tartu is available online: http://dspace. ut.ee/bitstream/handle/10062/46409/f101_linzbach.pdf?sequence=1\&isAllowed=y (viewed 1 February 2019). 


\section{Russian original}

$[416]$

19. История моего исследования

По причине, о которой речь будет ниже, я вынужден изложить здесь, в конце данного исследования, его историю, являющуюся историею моей жизни.

Родившись 9 июня, по старому стилю (или 21 июня, по[-]новому) 1874 г. в деревне Кыммасте прихода Ристи в Эстонии, мне скоро исполнится 78 лет. Из них 62 года проведено за данным исследованием. И началось оно вот каким образом.

Случилось так, что пастор, дававший в техническом училище, где я учился, уроки закона божия, \{заболев, учеников, заставили одних сидеть в классе. От нечего делать, мы устроили здесь нечто вроде [417] митинга, где речь шла о религии. Во время этого митинга ученик Леппик, который был на 3 года старше меня и которого я любил за защиту мою перед другими учениками, сказал мне:

- Неужели ты веришь в библию? Ведь то, что там написано о сотворении мира, противоречит физике!

Слова эти внезапно раскрыли мне глаза, ибо физику я тогда уже знал и, под влиянием преподавателя инженера Орлова, ею интересовался. Я понял, что учение библии действительно не вяжется с учением физики, и мне стало страшно. Казалось, что земля исчезает из[-]под моих ног, ибо в религии все было так просто, а теперь простота эта исчезла и все подвергалось сомнению.

Обстоятельство это было глубокою трагедиею моей 15-16 летней юности. И следствием его было то, что с тех пор я всю мою жизнь провел в изучении [418] философии, которою заинтересовал меня Леппик. А параллельно с изучением философии я, в качестве техника, занимался математикою, с глубоким значением которой познакомил меня инженер Орлов.

Изучение это продолжалось вплоть до большевистской революции. О характере и результатах его можно судить по изданной мною в 1916 году - за год до революции, когда я, по возрасту своему, опасался быть призванным в царскую армию - книге под заглавием:

Принциип философбского языка.

Опыт точного языкознания, Более 200 чертежей и таблиц в тексте.

$\mathrm{XII}+228$ страниц in $8^{\circ}$ 
Ч[т]обы дать понятие о содержании этой книги, я приведу здесь названия его [sic] 7 частей:

I. Об идеальном письме.

II. Об идеальном языке.

III. Об идеальных представлениях

[419] IV. Об идеальных понятиях.

V. Об идеальных знаках.

VI. Об идеальных выражениях.

VII. Об идеальной культуре.

И последняя часть эта состоит из 2 глав:

39. Раннее детство, как возраст изучения языка, и

40. Язык, как основа культуры. Взгляд на прошедшее и будущее человечества.

Из заглавий этих видно, что в книге этой я стоял уже на том же пути, по которому иду в излагаемом здесь универсальном языке. В главе об идеальных представлениях я ссылался уже на возможность применения картин и фильмов. А в главе об идеальной культуре я говорил уже о том, что в случае такого упрощения математики, при котором усваивание ее станет доступным и малым детям, человечество будет стоять настолько же выше современного человечества, насколько это последнее стоит, в силу обладания языком, выше животных, - цель, которую я ставлю себе и в изложенном здесь универсальном языке.

[420] Словом, в то время я преследовал уже ту же цель, которую преследую сейчас. И дальше я все больше и больше к ней приближался. Книга эта у меня сохранилась и интересующимся читателям я готов ее выслать.

Издание этой книги побудило меня к дальнейшей работе над ее темой, и в результате этого я в 1919 году демонстрировал на выставке районных художественных школ, где преподавал математическое черчение, схемы под названием «Геометрический язык». Схемы эти обратили на себя внимание посетившего выставку комиссара народного просвещения тов. Луначарского, приобретшего там и мою книгу. Вообще схемы эти обратили на себя внимание, и на выставку были командированы люди для снятия с них копий.

После выставки я схемы эти хранил, но впоследствии они сгорели в пожаре, о котором речь будет ниже. Помню теперь лишь то, что предложения [421] писались там в виде степеней, показатели которых соответствовали глаголам и были заключены в фигуры прямоугольников, что приводило к выражениям вроде 


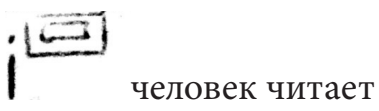

Из всего количества приведенных там выражений у меня осталась в памяти фигура:

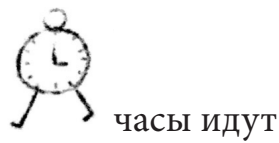

В 1920 году я в качестве оптанта, вернулся из Ленинграда в Таллин, который русские называли тогда Ревелем. И там же в следующем 1921 году написал и издал, на свои скудные средства, брошюру под заглавием:

Трансиендентная алгебра. Математическая идеография. Опьт философского языка. Ревель (Эстония), 1921

В брошюре этой я впервые стал на ту точку зрения, что проблема универсальной харак- [422] теристики Лейбница решается подстановкою в математические формулы, на место их букв, фигур, изображающих конкретные и отвлеченные предметы так, как они обозначаются в идеографии.

Брошюра эта была издана на международном языке окциденталь, на который перевел ее, по моей просьбе[,] изобретатель этого языка Е. фон Валь, под заглавием:

$$
\text { Jacob Linzbach }
$$

Transcendent algebra. Ideografie mathematical.

Experiment de un lingue filosofic.

Reval (Estonia), 1921

30 страниц in $32^{\circ}$

Перевод этот был сделан с целью распространения ее на западе, но сделать этого я, в качестве техника и неторговца, не сумел, и издание это осталось у меня на руках.

Вслед за этою брошюрою я издал здесь литограф[иче]ским способом, еще следующие работы. На немецком языке

[423] 1) Два номера журнала

N 1 März-April 1922 и

N² Mai-Juni 1922 
под названием:

Mathematische Ideographie. Zeitschrift für exacte Logik und Linguistik. Erscheint zweimonatlich

Журнал этот содержал мою статью:

«Die transcendentne Analysis. Differential- und Integralrechnung im

Denken und Vorstellen» von Jakob Linzbach

2) На русском языке я издал брошюру:

Прямолинейная геометрия высших измерений.

Наглядное представление пространства всякой степени от $x^{+\infty}$ до $x^{-\infty}$.

Я. Линцбах.

Автографированное издание с 69 чертежами в тексте.

Ревель, 1923

32 страницы in $8^{\circ}$

На брошюру эту так же, как и на немецкое издание, отзывались здесь лишь немногие.

[424] В 1924 году я поехал из Ревеля в Париж, с целью помогать там моему сыну, молодому художнику, - старший сын мой погиб в роли красного командира под Полтавою, куда он был отправлен для военных действий против Колчака. Содержал я в Париже себя и сына картографическою работою, которую производил у себя дома за задельную плату для литографий.

Устроившись, в смысле заработка, я[,] год спустя, издал, все тем же литограф[иче]ским способом, брошюру под заглавием:

J. Linzbach.

La géométrie et l'analyse géométrique de l’espace à $n$ dimensions.

Idéographie mathématique.

Exposé abrégé avec 26 figures dans le texte.

Traduit du russe par G. de Kolovrat.

Paris, 1925

18 страниц in $8^{\circ}$

В Париже я дополнил свои познания французского [425] языка, научившись мыслить и писать на нем самостоятельно, не нуждаясь в работе переводчика. В 1930-1931 гг. я издал здесь 25 номеров литографированного журнала под названием: 
Id[é]ographie mathématique.

Etude du langage philosophique par Jacob Linzbach

В журнале этом, заключавшем в себе в общем 200 страниц in $8^{\circ}[$,$] была$ помещена моя работа под заглавием:

Algèbre figurée. Interprétation idéographique de léquation du premier degré à une inconnue.

Потом номера эти были соединены в книгу под \{тем же\} названием:

Algèbre figurée. Interprétation idéographique de léquation du premier degré à une inconnue.

Paris, 1931

200 страниц in $8^{\circ}$

Работа эта была последнею, которую я там издал[,] и все другие оставались в рукописях.

[426] Вследствие оккупации Франции немцами, я в 1941 году вернулся с разрешения советских властей на родину, где[,] остановившись в Ревеле[,] продолжал работать над своими исследованиями. Но в ночь на 9 марта $\{1944$ г.\}, в результате воздушной бомбардировки Ревеля, здесь сгорели все мои книги и рукописи. А сам я, сидя в это время в убежище, остался в живых. Я решил тогда написать мои теории заново[,] и с тех пор, живя в самых тяжелых материальных условиях, я этим занимался, отказываясь, начиная c 25 III 1947 г., когда мне стали выплачивать рабочую пенсию в размере 210 рублей в месяц, от всякой другой работы. Благодаря этому все мое время уходило на восстановление сгоревшего.

Работая в таких условиях, я написал две работы, посылая их одну за другою на рассмотрение Академии наук СССР.

Первая работа была под заглавием:

[427] 1. Универсальная математика и универсальный язык.

Интуитивная математика - математика конкретная.

Ее принципь, метод и иель.

I-ое сообщение Академии наук Союза ССР и Эст. ССР

Я. Линцбах.

Таллин, 1949

В рукописи было 254 стр. 
Вторая работа была под заглавием:

2. Универсальная математика и универсальный язык.

Наглядное представление п-мерного пространства.

II-ое сообщение Академии наук Союза ССР и Эст. ССР

Я. Линцбах.

Таллин, 1950

В рукописи этой было 338 стр.

Посылая работы эти Академии, я естественно рассчитывал на их признание. И нет сомнения, что при нормальных условиях признание это имело бы место. Но помешало Академии мне его дать следующее обстоятельство.

[428] В июне 1950 года появилась работа тов. Сталина под заглавием:

И. Сталин

Относительно марксизма в языкознании.

К некоторым вопросам языкознания.

Издательство «Правды»

1950

В работе этой, говоря о грамматике языка, тов. Сталин настаивает на ее абстрактном характере. На стр. 22-23 его работы говорится об этом следующее:

«...Грамматика есть результат длительной, абстрагирующей работы человеческого мышления, показатель громадных успехов мышления.

«В этом отношении грамматика напоминает геометрию, которая дает свои законы[,] абстрагируясь от конкретных предметов, рассматривая предметы, как тела, лишенные конкретности, и определяя отношения между ними не как конкретные отношения таких-то конкретных предметов, а как отношения тел вообще, лишенные всякой конкретности.»

[429] Я же в моей работе изучал не грамматику языка, которая, будучи заменена здесь математическими формулами, имел[а] тот же абстрактный характер. Предметом моего изучения был словарный состав языка, конкретной природы которого не отрицает и тов. Сталин. На стр. 23 его работы сказано, что словарный состав языка подвергается изменениям, но основной словарный фонд сохраняется:

«Что же касается основного словарного фонда, то он сохраняется во всем основном и используется, как основа словарного состава языка,» цитата, свидетельствующая о том, что в учении тов. Сталина словарный состав языка имеет тот же конкретный характер, что и у меня. Абстрактного характера грамматики языка я не отрицал, ибо применял я ее здесь в виде 
формул отвлеченной математики. Абстрактное и конкретное были здесь связаны, представляя [430] две стороны языка, из которых абстрактное относится к грамматике языка, а конкретное к его словарному составу, составляемому здесь из его словарного фонда с помощью грамматики.

Подобно тому, как в арифметике, исходя из любого числа, взятого в качестве основания, можно составлять счисления, обозначающие все возможные числа, в области языка можно, исходя из произвольно взятого словарного фонда, создавать с помощью грамматики различные национальные языки, выражения которых являются, вследствие тождественности у них этой грамматики, переводимыми друг на друга. И в этом выражается здесь связь абстрактного, в лице грамматики языка, с конкретным, в лице его словарного состава. Различные языки, создаваемые таким образом, являются аналогичными различным системам счисления в области арифметики.

[431] Грамматика с ее абстрактною природою, на которую правильно указал тов. Сталин, служит здесь для того, чтобы[,] исходя из ограниченного числа слов его основного словарного фонда, составлять все остальные слова. И происходит это здесь подобно тому, как в арифметике, исходя из конкретного представления наших десяти пальцев, создалось десятичное счисление, с помощью которого можно обозначить и все остальные числа. Понятия абстрактного и конкретного являются здесь связанными и, дополняя друг друга, создают то, что в языке называется его словарем, его словарным составом, а в арифметике ее системою счисления, - в первом случае получается возможность выражения всех мыслимых слов, а во втором всех мыслимых чисел.

Сотрудники Академии[,] на рассмотрении которых были мои работы, обстоятельства этого не поняли. Видя же, что в работе своей я настаиваю на конкретном характере языка, тогда как тов. Сталин указывает [432] на его абстрактный характер, они заключили о существовании противоречи[й] моего учения учению тов. Сталина[.] И исходя из этого соображения, они работы мои, в виде негодных вещей, мне вернули, отказываясь, с ссылкою на учение тов. Сталина, от их признания.

Поступая так, члены Академии вели себя не в качестве ученых, а в качестве тех, которых тов. Сталин называет талмудистами. И этим они ввергли меня в невыносимое положение. Ибо при социализме признание научных исследований зависит от государственной власти, и Академия наук является здесь единственным учреждением, к которому можно обратиться.

Я пробовал спорить с Академиею. Но на возражения мои она не обратила внимания. И предо мною стал вопрос: что теперь делать? 
По поговорке нет худа без добра. Обстоятельство это [433] подтверждается и учением Протагора, о котором я говорил в главе 7 настоящего нового исследования. И в данном случае описанное здесь поведение Академии подсказало мне возможность непосредственного обращения к тов. Сталину, прося его быть судьею между мною и Академиею. Но для этой цели я решил снова переделать мои исследования, излагая их в этот раз с точки зрения учения тов. Сталина. На исполнение этой задачи пошли у меня последние два года, и в результате его получилось данное здесь новое более глубокое исследование моей проблемы; - исследование это состоит из двух частей, из которых вторая, под заглавием Универсальная математика, еще не переписана.

По часто повторяемому здесь изречению повторение есть мать учения, работа эта оказалась чрезвычайно полезною. Я открыл здесь, при следовании учению [434] тов. Сталина новые горизонты, которые и изложил в этой последней работе. Я называю ее последнею по той причине, что в виду моей старости у меня, по всей вероятности, не х[в]атит сил и времени для дальнейшего еще большего ее углубления. И делать это должны будут вместо меня другие исследователи.

Но работать над этою темою я буду до последнего моего издыхания. Вопрос лишь в том, хватит ли моих сил для окончательного просмотра и переписывания написанного. И это особенно в тех тяжелых материальных условиях, в которых я живу, будучи вынужден все сам себе делать, тратя на это свои силы и время.

Посылая теперь тов. Сталину и Академии наук настоящую новую работу, я жду от них решения ее судьбы[.] Остаюсь в твердой уверенности, что прежнее решении Академии будет [435] отменено и научная ценность мо[е]й работы признана. Обстоятельство же это очень важно, ибо речь идет здесь ни о чем другом, как о торжестве марксизма и об умственном развитии человечества в смысле поднятия его на высшую ступень эволюции, где, в силу приобретенного им математического мышления, оно будет стоять настолько же выше обыкновенного человечества, насколько это последнее, в силу обладания словесным языком, стоит выше бессловесных животных.

В заключение обращаю внимание читателей на то, что упорству и настойчивости, с которыми я работаю над данною теориею, отдавая ей досуги всей моей жизни, я обязан моей няне, старой деревенской деве Анне. По словам моей покойной матери, няня эта меня очень любила и, благодаря ее уходу, я начал говорить в полу- [436] годовом возрасте, проявляя интерес ко всем окружающим меня явлениям. 
- Когда что[-]либо[,] происходившее на крестьянском дворе[,] тебя заинтересовало, ты кричал ей: «vana Anne, vaatama! старая Анна, смотреть!» и она, схватив тебя под мышку и хромая, спешила туда, куда ты указывал.

Рас[с]казывая об этом, мать моя смеялась.

Высоко ценя такое отношение к детям, я одну из предыдущих работ, бывших на рассмотрении Академии, посвятил ее памяти. И делаю я это и здесь, несмотря на то, что настоящая работа посвящена тов. Сталину. Пусть память о ней, интеллектуальной воспитательницы моего детства, не забудется.

\section{English translation with comments ${ }^{8}$}

\section{History of my research}

For the reason that will be explained below, I have to present here, at the end of the present investigation, its history, which is the history of my life as well.

Having been born on 9 June according to the old calendar (or 21 June according to the new one) 1874 in the village of Kõmmaste in the Parish of Risti, Estonia ${ }^{9}$, I will soon turn 78. Of these, I have spent 62 years pursuing this study. And this is how it began.

It so happened that the pastor who taught God's law at the technical school where I was studying, had fallen ill and did not come to school and we, his students, were left to sit in class on our own. Having nothing to do, we arranged something like a debate there, devoted to religion. During this debate, one student, Leppik $^{10}$, who was three years my senior and whom I loved for he used to protect me from other students, said,

- Do you really believe in the Bible? After all, what is written there about the creation of the world goes against physics!

These words suddenly opened my eyes, for I already knew physics and, under the influence of our teacher, engineer Orlov ${ }^{11}$, was interested in it. I understood that, indeed, the teaching of the Bible was not concordant with the teaching of physics, and I became scared. It seemed that the ground was disappearing from beneath my feet, for in religion everything was so simple, but now that simplicity disappeared, and everything was to be questioned.

8 In this translatation, all the footnotes are by the author of this article.

9 Kõmmaste is located in the North-West of Estonia. Nowadays it remains in the LääneHarju Rural Municipality.

10 It was not possible to identify this Leppik.

11 It was not possible to identify this Orlov. 
That circumstance was a profound tragedy for me as a 15-16-year-old youth. And the consequence of it was that since then I have spent my whole life in the study of philosophy, in which Leppik interested me. And in parallel with philosophy, I, as a technologist [tehnik], have been involved in studying mathematics, the profound meaning of which had been revealed to me by engineer Orlov.

These studies continued until the Bolshevik revolution. Their nature and results can be judged by the book which I published in 1916, one year before the revolution, when I, because of my age, was afraid to be drafted into the Tsarist army, and which was entitled:

Printsipy filosofskogo yazyka. Opyt tochnogo yazykoznaniya,

Bolee 200 chertezhej i tablits v tekste.

XII+228 stranits in $8^{\circ 12}$

To give an idea of the content of this book, I will cite here the names of its seven parts:

I. On ideal writing.

II. On ideal language.

III. On ideal representations.

IV. On ideal notions.

V. On ideal signs.

VI. On ideal expressions.

VII. On ideal culture.

And this last part consists of two chapters:

39. Early childhood, as the age of language learning

40. Language as the basis of culture. A glance at the past and future of mankind.

It is evident from these titles that in this book I was already on the same path which I am currently following in presenting this universal language here. In the chapter on ideal representations I already mentioned the possibility of using pictures and films. And in the chapter on ideal culture I said that should mathematics be made simple enough to become accessible even to small children, humanity will stand as high above modern man as the latter does above animals because he possesses language - the goal that I set for myself also in the universal language presented here.

In a word, at that time I was already pursuing the same goal that I am pursuing now. And later I came nearer and nearer to it. I still have this book and I am ready to send a copy to those interested.

12 The Principles of Philosophical Language: An Attempt at Exact Linguistics, With more than 200 drawings and tables in the text. XII +228 pages in $8^{\circ}$. This book was republished in 2009 (see Lintsbah 2009[1916]). 
The publication of this book made me continue work on its theme; as a result, I presented, in 1919, some charts called "Geometric language" at the exhibition of the art schools of the district where I was teaching mathematical drawing ${ }^{13}$. The charts attracted the attention of the People's Commissar for Education, comrade Lunacharskij ${ }^{14}$, who visited the exhibition and bought my book there. In general, these charts were noticed, and people were sent to the exhibition to make copies after them.

After the exhibition, I kept those charts, but later they perished in a fire, which I will dwell on below. What I remember now is only that sentences were written there as powers corresponding to verbs, which were enclosed in rectangular boxes, which led to expressions such as:

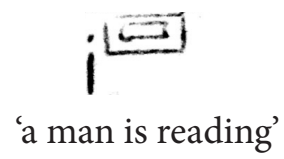

Of the entire multitude of expressions given there, my memory has preserved only

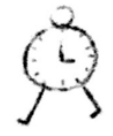

'the clock is ticking'

In 1920, as an optant, I returned from Leningrad ${ }^{15}$ to Tallinn that the Russians would then call Revel ${ }^{16}$. And there, in the following year, 1921, I wrote and published, by my meager means, a brochure entitled:

Transtsendentnaya algebra. Matematicheskaya ideografiya.

Opyt filosofskogo yazyka.

Revel' (Estoniya), $1921^{17}$

13 No information has been found concerning this exhibition and the school where Linzbach taught mathematical drawing.

14 Anatolij Vasil'evich Lunacharskij (1875-1933) was People's Commissar for Education from 1917 to 1929. In this position he fought successfully against illiteracy in the Soviet Union and supported different innovative tendencies in art and culture (on Lunacharskij, see Fitzpatrick 1970).

15 Before moving back to Estonia, Linzbach thus lived in Russia. His Principles were published in Petrograd, which was the name of Leningrad-St.Petersburg from 1914 to 1924.

16 The capital of Estonia received its actual name Tallinn in 1918, when Estonia became independent. Its German and Russian names, Reval and Revel', respectively, were still commonly used, though.

17 Transcendental Algebra. Mathematical Ideography. An Attempt at a Philosophical Language. Reval (Estonia), 1921. 
In the brochure, for the first time, I took up a position that the problem of the universal characteristic of Leibniz ${ }^{18}$ can be solved by substituting figures representing concrete and abstract objects for letters in mathematical formulas, as in ideographic representations.

This brochure was published in the international language Occidental ${ }^{19}$, into which, at my request, the inventor of this language, E. von Wahl ${ }^{20}$, translated it under the title:

\author{
Jacob $^{21}$ Linzbach \\ Transcendent algebra. Ideografie mathematical. \\ Experiment de un lingue filosofic. \\ Reval (Estonia), 1921 \\ 30 pages in $32^{\circ 22}$
}

18 The 17th century was characterized by what James Knowlson (1975) has called "universal language schemes". Among the different authors involved in the creation of universal languages (John Wilkins [1614-1672], Comenius [1592-1670], Dalgarno [c. 1616-1684], Descartes [1596-1650], etc.), Leibniz and his characteristica universalis occupy an important place. The main goal of Leibniz and of all his peers was the construction of "a universal writing system, a real character composed with ideographic signs which they believed directly referred not to words but to things or to notions of things" (Slaughter 1982: 1). The universal language of Leibniz's project "was to be formed by means of an analysis of complex concepts into their simplest constituent elements" and "every complex concept would be represented by a combination of signs each of which represented individually one of its simple constituent elements" (Knowlson 1975: 108). On Leibniz, see Couturat 1961[1901].

19 Edgar de/von Wahl (1867-1948) was an Estonian interlinguist and the creator, in 1922, of the artificial language called first Occidental and then Interlingue (Dulichenko 1990: 219-220). According to Henry Jacob (1947: 60), de Wahl "studied Volapük in 1887 and took up Esperanto a year later only to give it up again and to begin his independent studies in 1894 . He turned his interest to a naturalistic solution of the problem". In 1922, he published his project Occidental (Wahl 1922) that followed one of his principles according to which an international language "should be based on the international forms common to the European languages in phonetics, spelling, and mode of expression" (Jacob 1947: 60).

De Wahl and Linzbach were, with others, behind the creation of the Kosmoglot Society for the International Language in Petrograd in 1916; in 1921 the society was relocated to Tallinn under the name of Kosmoglott at the initiative of de Wahl and Linzbach. As president of the society Kosmoglott, Linzbach was among the two signatories of the letter in French that the society sent to the League of Nations in 1921, asking for the involvement of the League in the resolution of the question of an international language (this letter and the responses of the League of Nations are published in the first issue of the journal Kosmoglott (February 1922, p. 3-5). For a history of this interlinguistic society and for other facts concerning Linzbach as president/member of this society, see Kuznetsov 2016.

20 See Footnote 19.

21 When using the Latin alphabet, Linzbach spelled his name as 'Jacob' in his works in French or in Occidental, and as 'Jakob' in his works in German.

22 See Linzbach 1921. It is not clear from Linzbach's text if this brochure in Occidental was first published in Russian. Apparently, such a brochure does not exist in Russian. Concerning 
This translation was made with the aim of distributing it in the West, but, being a technologist rather than a tradesman, I was unable to do this, so this publication remained in my possession.

After this brochure I also published here, lithographically, the following works. In German:

1) Two issues of the journal:

$\mathrm{N}^{\circ} 1$ March-April 1922 and

$\mathrm{N}^{\circ} 2$ May-June 1922

entitled

Mathematische Ideographie. Zeitschrift für exacte Logik und Linguistik. Erscheint zweimonatlich

This journal contained my article: ${ }^{23}$

"Die transcendentne Analysis. Differential- und Integralrechnung im

Denken und Vorstellen" von Jakob Linzbach

2) In Russian I published the brochure

Pryamolinejnaya geometriya vysshih izmerij. Naglyadnoe predstavlenie prostranstva vsyakoj stepeni ot $x^{+\infty}$ do $x^{-\infty}$.

Ya. Lintsbah.

Avtografirovannoe izdanie c 69 chertezhami v tekste.

Revel', 1923

32 stranitsy in $8^{\circ 24}$

Only very few people responded to this brochure, which was also the case with the publication in German ${ }^{25}$.

the brochure in Occidental, it appears to be the first ever publication in this artificial language (Wahl 1930: 31), even before the publication of the first issue of the journal Kosmoglott in 1922 that was mainly written in Occidental; 1922 is the year of the appearance of Occidental (see Footnote 19).

23 Mathematical Ideography. Journal of Exact Logic and Linguistics. Published bimonthly.

24 Rectilinear Geometry of Higher Dimensions. A Visual Representation of the Space of Each Degree from $x^{+\infty}$ to $x^{-\infty}$. J. Linzbach. Autographed edition with 69 drawings in the text. Reval, 1923, 30 pages in $8^{\circ}$.

25 The journal Kosmoglott ( $\mathrm{N}^{\circ} 3$, April 1922, p. 16 and $\mathrm{N}^{\circ}$ 5, June 1922, p. 32), that was the "organ del Societé Kosmoglott" of which Linzbach was president (see Footnote 19) contains information concerning the publication of Linzbach's journal in German Mathematische Ideographie. See Footnote 32. 
In 1924, I moved from Reval to Paris, with the aim of helping my son, a young $\operatorname{artist}^{26}$; my elder son was killed as a Red Commander at Poltava ${ }^{27}$, where he was sent to fight Kolchak ${ }^{28}$. In Paris ${ }^{29}$, I supported my son and myself by cartographic work, which I was doing at home, paid per lithograph. Well off in terms of earnings, I published, a year later, also lithographically, a brochure entitled:

\section{J. Linzbach.}

La géométrie et l'analyse géométrique de l'espace à $n$ dimensions. Idéographie mathématique.

Exposé abrégé avec 26 figures dans le texte.

Traduit du russe par G. de Kolovrat ${ }^{30}$.

Paris, 1925

18 pages in $8^{\circ}$

26 The son's name was Peeter (in French: Pierre) Linzbach and he was born on 16 August 1902. See Footnote 29.

27 Poltava is a city now located in central Ukraine.

28 Aleksandr Vasilevich Kolchak (1874-1920) was an Imperial Russian admiral. During the Russian Civil War (1917-1923), he was one of the leaders of the White Army that fought against communism and Bolshevik rule. In 1918 he established the anti-communist Provisional All-Russian Government and became the Supreme Leader and Commander-in-Chief of All Russian Land and Sea Forces. He was executed by the Bolsheviks in February 1920.

29 Linzbach's stay in Paris from 1924 to 1941 remains unexplored and not very well known, even if it is talked about briefly in Dulichenko 2005 and Kruus 1988. For example, there is no file "Jakob Linzbach" in the archives of the Préfecture de police de Paris that was in charge of foreigners, yet there is a file concerning Jakob Linzbach's son Peeter, registered at the end of 1936 as a painter [artiste-peintre] living at 51, rue Pierre-Demours. Paris $17^{\mathrm{e}}$ (mail from the archives of the Préfecture de police, 27 October 2016). A letter written by Linzbach from Paris to mathematician and creator of the artificial language Latino sine flexione/Interlingua (1903) Giuseppe Peano (1858-1932) and kept in Peano's archives says that Linzabch lived at 28, rue Ducouëdic in the $14^{\text {th }}$ arrondissement of Paris (Roero et al. 2008). More information can be found in the Dictionary of Russian Emigration in France (Mnuhin et al. 2008-2010): while in Paris, Linzbach participated in the activities of the Russian Scientifico-Philosophical Society [Nauchno-filosofskoe obshchestvo] by giving lectures and, in 1936, he made a presentation at the seminar on hydraulics of professor Adrian Vasilevich Dejsha (1886-1952) at the Russian Faculty of Physics and Mathematics at the Sorbonne. The Dictionary also mentions that Linzbach was a Freemason. About the possible contacts that Linzbach may have had with the Parisian linguists, see Footnote 30.

30 According to Mnuhin et al. 2008-2010, George de Kolovrat or Kolowrat was born in St. Petersburg as Yurij (Georgij) Stanislavovich Kolovrat-Chervinskij and died on 26 February 1943 in Monaco. He was a linguist, translator and composer. In St. Petersburg, he graduated from the Faculty of Oriental Languages of the University before emigrating to France. There he continued his studies at the Sorbonne, where he defended two theses (probably in 1923) that were reviewed without enthusiasm by famous French linguist Antoine Meillet (1866-1936) (see Meillet 1923, 1924). On 21 April 1923 (Bulletin de la Société de linguistique de Paris, 1923, t. 24: XX) he was 
In Paris I increased my knowledge of the French language ${ }^{31}$, learning to think and write in it, not relying on an interpreter. In 1930-31, I published there 25 issues of the lithographed journal called:

\author{
Idéographie mathématique. Etude du langage philosophique \\ par Jacob Linzbach ${ }^{32}$
}

elected member of the Société de linguistique de Paris and attended several meetings of the Society along with some of the most famous French linguists of the time: for example, on 24 March 1928 the meeting brought together Kolovrat with, among others, Meillet, Emile Benveniste (1902-1976), André Mazon (1881-1967), Joseph Vendryes (1875-1960), and Henri Maspéro (1883-1945) (Bulletin de la Société de linguistique de Paris, 1928-1929, t. 29: XX). Kolovrat was also interested in artificial languages. He published a Russian-language a handbook of Esperanto (Kolovrat-Chervinskij 1905), collaborated with Esperanto journals (Stojan 1929: 289, 312, 321) and wrote about Esperanto and Ido (see Kolowrat 1908, 1909). He was also involved in the movement promoting Peano's Latino sine flexione/Interlingua, was member of the Academia pro Interlingua (see Academia pro Interlingua-Circulares, 20 February 1924, 14), corresponded with Peano (dozens of letters to Peano are kept in Peano's archives [see Roero et al. 2008]) and published articles in Latino sine flexion/Interlingua in different journals of the movement.

Being the translator into French of one of Linzbach's works, Kolovrat probably met with Linzbach regularly in Paris. One of the questions remaining unanswered is whether Linzbach, through Kolovrat, met some local linguists while in Paris, or did not. Apparently, as far as can be seen from a careful examination of the Bulletin de la Société de linguistique de Paris, Linzbach did not attend any meetings of the Society, not even as a guest.

31 As can be judged by, for example, his journal Idéographie mathématique written in French (Linzbach 1931) or his letter to Peano (Roero et al. 2008), Linzbach's French was quite good.

32 The journal Schola et Vita, that was one of the organs of the Academia pro Interlingua (which was another name for Peano's Latino sine flexione [see Footnotes 29 and 30]) published in its January-March issue in 1930 ( $\left.\mathrm{N}^{\circ} 1-3: 12\right)$ a short review of the first issues of Linzbach's Idéographie mathématique. In the journal Cosmoglotta which was the "organ bimensual" of the movement for de Wahl's language Occidental, a more detailed review by de Wahl himself (Wahl 1930) of Idéographie mathématique appeared. Here are the main points of the review in the original Occidental language: "Sr. J. Linzbach, li conosset pasigraphist [...] presenta se al publica con un plen matur systema. [...] On posse esser ye divers opinion pri li practice applicabilitá de un tal mathematico-philosophic pasigraphie, ma it es cert que li profund e original idées del autor va dever interessar omni modern philosoph e linguist. It es conosset que mult fundamental progress technic ha esset debet al phantastic idées de pensatores e experimentatores. It es sufficent mentionar li meditationes astronomic, li luderies electric, e li enorm signification quel ili ha atinet in li modern tempor. Noi save que anc li lingue chinesi esset in commensal un ideographie, poy desapparit in su claritá per manual scrition. Ma ti ideographie es un ligament cultural de omni ost-asiates. Pro to un tal standardisat pasigraphie anc for nos forsan posse haver in future un tre practice signification in tal libres queles vole standardisar logic, philosophic, technic e altri conceptions quam p. ex. encyclopedies, lexicos descriptive etc. On save que p. ex. un parol de un lingue nequande corresponde absolumen a un tal de un altri lingue in su significations. Li adjuntion del absolut logic ideographic signe ci do vell posser esser de grand importantie." Likewise, there is an advertisement of the publication of Idéographie mathématique in the same, March-April issue of Cosmoglotta ((1930, $\mathrm{N}^{\circ}$ 69: 43). 
In this journal, which included a total of 200 pages in $8^{\circ}$, my work was published under the title

\section{Algèbre figurée. Interprétation idéographique de l’équation du premier} degré à une inconnue.

Later, these issues were collected into a book under the same title: Algèbre figurée. Interprétation idéographique de l'équation du premier degré à une inconnue.

Paris, 1931

200 pages in $8^{\circ 33}$

This work was the last one I published there; all the other works remained in manuscript.

Due to the occupation of France by the Germans, in 1941 I returned to my homeland with the permission of the authorities, where I stayed in Reval and continued my research. But on the night of 9 March 1944, as a result of the air bombing of Reval, all my books and manuscripts were burnt. As for me, I was in a shelter and managed to stay alive. I decided then to write my theory anew and since then, living in the most difficult material conditions, I have been doing this, renouncing any other job offers starting from 25 March 1947, when I started to receive a working pension of 210 rubles a month. Thanks to this all my time has been spent on the restoration of what was burnt.

Working under such conditions, I wrote two works, sending them to the Academy of Sciences of the USSR for consideration, one after the other.

The first work was called:

1. Universal'naya matematika $i$ universal'nyj yazyk.

Intuitivnaya matematika - matematika konkretnaya. Ee printsipy, metod i tsel'.

I-oe soobshchenie Akademii nauk Soyuza SSR i Ėst. SSR

Ya. Lintsbah.

Tallin, $1949^{34}$

33 Linzbach 1931. This is what it says in the "Foreword": "The current journal bearing the title 'Mathematical Ideography' is a personal organ published by the author. Its purpose is the disclosure of his works to allow them to be criticized before their final typographical edition. The latter, being expensive because of the large number of ideographic figures employed in the text, can only be realized much later, when the importance of the theories in question will have received recognition by authorities - mathematical, philosophical and literary. [...] The newspaper will appear one or more times a month" (Linzbach 1931: III).

34 Universal Mathematics and the Universal Language. Intuitive Mathematics as Concrete Mathematics. Its Principles, Method and Purpose. First Message to the Academy of Sciences of 
The manuscript contained 254 pages.

The second work was called:

2. Universal'naya matematika i universal'nyj yazyk.

Naglyadnoe predstavlenie n-mernogo prostranstva.

II-oe soobshchenie Akademii nauk Soyuza SSR i Èst. SSR

Ya. Lintsbah.

Tallin, $1950^{35}$

This manuscript contained 338 pages.

Sending these works to the Academy, I naturally was counting on recognition ${ }^{36}$. And no doubt, under normal conditions ${ }^{37}$ this recognition would have taken place. But the following circumstance precluded the Academy from giving the recognition to me. In June 1950 Comrade Stalin's work ${ }^{38}$ appeared under the title:

the USSR and Est[onian] SSR. J. Linzbach. Tallin, 1949. This manuscript is not among the documents kept in Linzbach's fond (fond 101) in the archives of the library of the University of Tartu. However, this manuscript still seems to exist: Sergej Kuznetsov (2016: 140) writes that he has a copy of it. See Footnote 42.

35 Universal Mathematics and Universal Language. A Visual Representation of an n-Dimensional Space. Second Message to the Academy of Sciences of the USSR and Est[onian] SSR. J. Linzbach. Tallin, 1950. This manuscript is kept in Linzbach's fond (fond 101, item 5) in the archives of the library of the University of Tartu. Here, Linzbach wrote "II-oe soobshchenie Akademii nauk [Second message to the Academy of Sciences]", but the original document reads "II-oe soobshchenie Akademiyam nauk [to the Academie of Sciences]" (Lintsbah 1950a).

36 Linzbach seemed to be fairly sure that his works would be recognized by the Academy. For example, in one of his manuscripts, he says that the "negative feedback [otzyv]" of the Academy was "unexpected" and that "at first [he] could not believe [his] eyes" (Lintsbah 1950c: 1).

37 See Footnote 38.

38 Linzbach sent his two works to the Academy at the end of July 1949 (the first one) and at the end of April or beginning of May 1950 (the second one) (Lintsbah 1950a: VI). On 25 May 1950, he wrote another letter to the Academy, urging it to work faster on his works (Lintsbah 1950b: 3). As will be shown, Spring 1950 was a very special period for Soviet linguistics.

On 9 May 1950, the editors of Pravda [Truth], the official newspaper of the Communist Party of the Soviet Union, considering "the unsatisfactory state of Soviet linguistics", decided "to organize an open discussion [...] in order, through criticism and self-criticism, to overcome stagnation in the development of Soviet linguistics and to give correct direction to further work in the field" (quoted from Pollock 2006: 114). This was the beginning of the so called "linguistic discussion". Since approximately the mid-1920s, the linguistic theories of Nikolaj Yakovlevich Marr (1864-1934) had been considered "the one and only path for Soviet linguistics" (Pollock 2006: 106) that was, from the beginning of the 1920s, trying to pave the way to a Marxist way of doing linguistics (on Marr's linguistics, see Thomas 1957 and Velmezova 2007). The Soviet authorities, indeed, "talked about the creation of a new society on the basis of science, according to which it was necessary to formulate a 'new science' based on the ideas of Marxism" (Alpatov 
2010: 18). The Marxism of Marr's linguistic theories can be summed up as follows: for him, the language was a superstructure and, like all superstructures according to Marx's teaching, it is subject to the changings occurring in the basis: then, in Marr's theory, "languages skipped from one stage of their development to another in direct correspondence to the modes of production identified by Marx" (Pollock 2006: 105); therefore, Marr thought that "languages were linked by their state of development, not by a common protolanguage" (Pollock 2006: 105) as was taught by the so-called "bourgeois" Indo-European linguistics. Following this refusal of genetically related language families, Marr's Marxist linguistics also explained that languages were a class phenomenon, that led to the famous assertion of Marr that "same-class languages from different countries - given an identical social structure - are more similar typologically than the languages of different classes within the same country, the same nation" (Marr 1936[1929]: 415, quoted and translated by Slezkine 1996: 843). Against the teaching of Indo-European linguistics for which languages developed from a few proto-languages towards the different, multiple languages we know now, Marr also asserted that all languages would follow an exactly opposite process: in relation with the expansion of communism and brotherhood of workers, classes and nations would disappear and, through close and friendly contacts, languages would merge into one common world language that, according to Stalin who promoted this idea of Marr in a speech at the 16th Congress of the Communist Party of the Soviet Union in 1930 and thus made it official, would "be neither Great-Russian nor German, but something new" [Stalin, Joseph 1930. Reply to the discussion on the political report of the Central Committee to the Sixteenth Congress of the C.P.S.U.(B.). Marxist Internet Archive, is available at https:// www.marxists.org/reference/archive/stalin/works/1930/07/02.htm (viewed 1 February 2019)]. This is what Soviets linguistics looked like till the linguistic discussion of 1950.

After more than a month, on 20 June 1950, the linguistic discussion was dealt a decisive blow. After having published since May articles that were either neutral, pro or contra Marr, Pravda published an article by Stalin himself that was about to "completely [alter] the field of Soviet linguistics" (Pollock 2006: 123). In this article entitled "Concerning Marxism in linguistics" (later published as a booklet with other articles that Stalin wrote after the first one still as parts of the linguistic discussion [Stalin, Josef 1950. Marxism and problems of linguistics. Marxist Internet Archive, is available at https://www.marxists.org/reference/archive/stalin/works/1950/ jun/20.htm (viewed 1 February 2019)], Stalin repudiated Marrism, asserting that Marr "was nothing but a simplifier and vulgarizer of Marxism" (Stalin 1950): "N. Y. Marr introduced into linguistics an immodest, boastful, arrogant tone alien to Marxism and tending towards a bald and off-hand negation of everything done in linguistics prior to N. Y. Marr" (Stalin 1950). According to Stalin - who led the new way that Soviet linguistics would follow - languages were not superstructures ("Language is not a product of one or another base, old or new, within the given society, but of the whole course of the history of the society and of the history of the bases for many centuries." [Stalin 1950]), nor were they class based ("The 'class character' of language formula is erroneous and non-Marxist" [Stalin 1950]). This was the beginning of a new era in Soviet linguistics that underwent deep, theoretical and institutional reorganization (Pollock 2006: 127-133).

The reasons why Stalin suddenly decided to reject Marr's theories that he had been supporting for more than 20 years are not definitely settled. Several authors have provided different explanations, besides "the unsatisfactory state of Soviet linguistics" and "the unhealthy 


\section{Stalin}

Otnositel'no marksizma v yazykoznanii. K nekotorym voprosam yazykoznaniya. Izdatel'stvo "Pravdy"

$1950^{39}$

In this work, speaking about the grammar of a language, comrade Stalin insists on its abstract nature. On pages 22-23 of his work, he says the following: "Grammar is the outcome of a process of abstraction performed by the human mind over a long period of time; it is an indication of the tremendous achievement of thought.

In this respect grammar resembles geometry, which in giving its laws abstracts itself from concrete objects, regarding objects as bodies devoid of concreteness, and defining the relations between them not as the concrete relations of concrete objects but as the relations of bodies in general, devoid of all concreteness" 40

In my work I did not study the grammar of a language, which, having been replaced here with mathematical formulas, had the same abstract nature. The object of my study was the vocabulary [slovarnyj sostav] of a language, the concrete nature of which Comrade Stalin does not deny. Page 23 of his work says that the vocabulary of a language undergoes changes, but the basic stock of words [osnovnoj slovarnyj fond] remains:

"As to the basic word stock, it is preserved in all its fundamentals and is used as the basis for the vocabulary of the language" ${ }^{41}$ This is a quote that shows that, in the teachings of Comrade Stalin, the vocabulary of the language [slovarnyj sostav yazyka] has the same concrete character that it has in my work. I did not deny the abstract nature of the grammar of a language, for I introduced it here in the form of formulas of abstract mathematics. The abstract and the concrete were connected here, representing the two sides of a language: where the abstract refers to the grammar of the language, and the concrete to its vocabulary [slovarnyj

dominance Marr's disciples maintained over Soviet linguistics" (Pollock 2006: 112, 114). For Ethan Pollock (2006: 128), "Marr's transnational linguistic theory" did not fit "with the patriotic fervor of the era" after World War II anymore; Ekaterina Velmezova (2014: 257-314) highlights other aspects of the Soviet political context of the time to explain Stalin's intervention in linguistics, such as the new importance of the Slavic brotherhood and the "Chinese question" for the Soviet Union, or the place that Marr's theory assigned to Georgian, the mother tongue of Stalin.

Linzbach, thus, sent his works to the Academy of Sciences for consideration in a very special period, when Soviet linguistics was undergoing deep changes and reconsiderations.

39 Stalin, Concerning Marxism in Linguistics. On Some Questions of Linguistics. "Pravda" Publishers, 1950.

40 Stalin 1950.

41 Stalin 1950. 
sostav] that is compiled here from the stock of words with the help of the grammar.

Just as in arithmetic where, proceeding from any number taken as a base, it is possible to make calculations denoting all possible numbers, so in the field of language it is possible, proceeding from an arbitrarily chosen stock of words, to create, with the help of grammar, various national languages whose expressions are, as a consequence of the identity of their grammar, mutually translatable. And in this the connection between the abstract, represented by the grammar of a language, and the concrete, represented by its vocabulary, is expressed. The different languages created in this way are similar to the various systems of calculation [sistema schisleniya] in the field of arithmetic.

Grammar, with its abstract nature, which comrade Stalin correctly pointed out, serves here, proceeding from the limited number of words of its basic word stock, to make all other words. And this takes place here just as in arithmetic when, on the basis of the concrete representation of our ten fingers, decimal calculation was created, with the help of which it is possible to denote all the other numbers. The concepts of the abstract and the concrete are connected here and, complementing each other, they create in a language what is called its lexicon [slovar'], its vocabulary [slovarnyj sostav], and in arithmetic what is called its numeral system [sistema schisleniya]; in the former case it becomes possible to express all conceivable words, and in the latter case, all the conceivable numbers.

The staff of the Academy, to whom I submitted my works for consideration, did not understand this circumstance. Seeing that in my work I insist on the concrete nature of language, whereas Comrade Stalin points to its abstract character, they concluded that a discrepancy existed between my teaching and the teaching of Comrade Stalin and, on the basis of this, they returned my works ${ }^{42}$ as valueless, and, referring to the teaching of Comrade Stalin, refused to recognize them ${ }^{43}$.

42 According to Linzbach, his two works were sent back to him by the Academy. The fact that his 1949 manuscript sent to the Academy is not among the documents kept in Tartu (see Footnote 34) remains unexplained. One of the explanations could be that this manuscript was not sent back to Linzbach and is therefore now in the archives of the Academy of Sciences in Moscow.

43 Linzbach's fond has kept a copy (probably sent to Linzbach) of the evaluation that the Steklov Mathematical Institute hade made of Linzbach's Universal Geometry (Lintsbah 1950a). In this evaluation for the office of the Presidium of the Academy of Sciences of the USSR, it is written that Linzbach's "manuscript is of no interest" (Archives of the Library of the University of Tartu, Tartu (Estonia), fond 101, item 8). From another manuscript by Linzbach we know that the Mathematical Institute also asked Linzbach to refer to Stalin's work about Marxism and linguistics (Lintsbah 1950c: 3). 
By doing this, the members of the Academy did not behave as scientists, but as those whom Comrade Stalin calls Talmudists ${ }^{44}$. And by this they put me into an unbearable situation. For, under Socialism, recognition of scientific research depends on the State power and the Academy of Sciences is here the only institution to which it is possible to turn.

I tried to argue with the Academy ${ }^{45}$. But the Academy did not pay any attention to my objections. And I was faced with the question what to do next.

According to the proverb, every cloud has a silver lining. This circumstance is confirmed by Protagoras' teaching, which I spoke about in Chapter 7 of this new study $^{46}$. In this case, the behaviour of the Academy described here suggested that I should appeal directly to Comrade Stalin ${ }^{47}$, asking him to be the arbiter between the Academy and me. But for this purpose, I decided to do my research again, this time from the point of view of Comrade Stalin's teaching. I have been fulfilling this task for the past two years, and as a result, a new, more profound study of my issues has been achieved: this study consists of two parts, the second of which, titled Universal Mathematics, has not yet been rewritten.

According to the oft-repeated saying, repetition is the mother of learning; thus, this work has been extremely useful. Following the teachings of comrade Stalin, I have revealed new horizons that I have outlined in my last work. I call it the last one, because, in view of my old age, I, in all probability, will have neither strength nor time to pursue it further. And other researchers will have to replace me in doing this.

But I will work on this theme until my last breath. The only question is whether I will have enough strength to review and rewrite completely what was written ${ }^{48}$. And particularly considering the difficult material conditions in which I am living, being forced to do everything myself, spending on this my time and my energy.

44 Here is what Stalin said about "Talmudists" in his 1950 article concerning Marxism in linguistics: "That is always the case with textualists and Talmudists who do not delve into the essence of the matter, quote mechanically and irrespective of the historical conditions of which the quotations treat, and invariably find themselves in a hopeless situation" (Stalin 1950).

45 Probably at the end of November 1950, Linzbach sent his "third message to the Academy of Sciences of the Soviet Union" (written between 30 September and 20 November), in which he pointed out the "narrow thinking" of the Academy and tried to "give [...] further insights and generalizations of [his] theories" (Lintsbah 1950c: 28 and 31).

46 See Lintsbah 1951-1952: 135-148.

47 The work in which this autobiography appears is dedicated to "Com. Iosif Vissarionovich Stalin on the occasion of his work: 'Concerning Marxism in Linguistics"' (Lintsbah 19511952).

48 As Linzbach died in 1953, he probably did not have an opportunity to rewrite the second part that he talks about here. 
Sending now my new work to Comrade Stalin and the Academy of Sciences, I will be waiting for their decision on its fate. I remain firmly convinced that the previous decision of the Academy will be cancelled and that the scientific value of my work will be recognized ${ }^{49}$. This circumstance is very important, for it means nothing else but the triumph of Marxism and the intellectual development of mankind in the sense of elevating it to a superior stage of evolution, where, by virtue of the mathematical thinking acquired, mankind will stand higher than the ordinary humanity that stands, due to the possession of a verbal language, above the speechless animals.

In conclusion, I draw the readers' attention to the fact that I owe the persistence and insistence with which I have been working on this theory, devoting to it all the free time of my life, to my nanny, an old village maid Anna ${ }^{50}$. According to my late mother, this nanny loved me very much and, thanks to her care, I started talking at the age of six months and showed interest in all the phenomena around me.

- When anything that happened in the farm yard interested you, you shouted to her: "vana Anne, vaatama! ${ }^{11}$ Old Anna, let's have a look!" And she grabbed you under your arms and hurried, limping, where you indicated.

Saying this, my mother laughed.

Highly praising this attitude towards children, I dedicated one of the previous works that were submitted for the Academy's consideration to my nanny ${ }^{52}$. And I am doing this here too, even though the present work is dedicated to comrade Stalin. May the memory of the intellectual caretaker of my childhood not be forgotten.

\footnotetext{
49 We know the fate of this "new work" that Linzbach sent to the Academy of Sciences. Linzbach's fond in Tartu contains a letter sent to Linzbach on 17 April 1952 by the chemist Aleksandr Vasilevich Topchiev (1907-1962), chief scientific secretary of the Presidium of the Academy of Sciences of the USSR. In this letter, Topchiev informed Linzbach that his manuscript was reviewed by the Steklov Mathematical Institute and by the Institute of Linguistics (both belonging to the Academy of Sciences) but "got a negative rating" and that, therefore, it had been sent back to him. This 1951-1952 manuscript was also sent back to Linzbach, as had been the case with the other works that he sent to the Academy for consideration (see Footnotes 34 and 42).

50 No information has been found concerning this Anna.

51 In Estonian in the original.

52 This "previous work" could not be identified.
} 


\section{References}

Alpatov, Vladimir M. 2010. Soviet linguistics of the 1920s and 1930s and the scholarly heritage. In: Brandist, Craig; Chown, Katya (eds.), Politics and the Theory of Language in the USRR 1917-1938: The Birth of Sociological Linguistics. London: Anthem Press, 17-34.

Couturat, Louis 1961[1901]. La logique de Leibniz d'après des documents inédits. Hildesheim: Georg Olms Verlagsbuchhandlung.

Drezen, Ernest 1991[1931]. Historio de la mondolingvo. Tri jarcentoj da serĉado. Moskvo: Progreso, 1991.

Dulichenko, Aleksandr 1990. Mezhdunarodnye vspomogatel'nye yazyki. Tallinn: Valgus.

- 2005: Ob idee universal'nogo yazyka Yakoba Lintsbaha (predvaritel'nye zamechaniya). Interlinguistica Tartuensis 8: 121-128.

Florenskij, Pavel Aleksandrovich 1988[1918]. Antinomiya yazyka. Voprosy yazykoznaniya 6: $88-125$.

Eco, Umberto 1976. A Theory of Semiotics. Bloomington: Indiana University Press.

Fitzpatrick, Sheila 1970. The Commissariat of Enlightenment: Soviet Organization of Education and the Arts under Lunacharsky, October 1917-1921. Cambridge: Cambridge University Press.

Ivanov, Vyacheslav Vsevolodovich 1977. Predislovie. In: Revzin, Isaak Iosifovich (ed.), Sovremennaya strukturnaya lingvistika: Problemy i metody. Moscow: Nauka, 3-6.

Jacob, Henry 1947. A Planned Auxiliary Language. London: Dennis Dobson Limited.

Janton, Pierre 1993. Esperanto: Language, Literature, and Community. Albany: State University of New York Press.

Knowlson, James 1975. Universal Language Schemes in England and France, 1600-1800. Toronto: University of Toronto Press.

Kolovrat-Chervinskij, [Georgij] 1905. Kurs mezhdunarodnogo yazyka Ėsperanto $v 6$ urokax. Sankt-Peterburg: Litografiya Bogdanova.

Kolowrat, Georges 1908. Faut-il réformer l'Espéranto? Paris: Presa esperantista societo.

- 1909. Pri la derivo en Ido kaj Esperanto. Paris: Presa esperantista societo.

Kristeva, Julia 1967. L'expansion de la sémiotique. Informations sur les sciences sociales (October): 169-181.

Kruus, Rein 1988: K biografii Ya. Lintsbaha. In: Dulichenko, Aleksandr (ed.), Planovye yazyki: itogi i perspektivy. Tezisy dokladov konferencii po interlingvistike (Tartu, 22-24 oktyabrya 1987). Tartu: Tartuskij gosudarstvennyj universitet [University of Tartu], Filologicheskij fakul'tet, 31-35.

Kull, Kalevi; Salupere, Silvi; Torop, Peeter 2005. Semiotics has no beginning. In: Deely, John, Basics of Semiotics. (Tartu Semiotics Library 4.) Tartu: Tartu University Press, ix-Xxv.

Kuznetsov, Sergej 2016. Petrogradskoe interlingvisticheskoe obshchestvo "Kosmoglot". K stoletiyu osnovaniya (1916-2016). Sovremennaya nauka 1: 111-152.

Lintsbah, Yakov Ivanovich 2009[1916]. Printsipy filosofskogo yazyka. Opyt tochnogo yazykoznaniya. Moscow: URSS.

- 1950a. Universal'naya matematika i universal'nyj yazyk. Universal'naya geometriya. Naglyadnoe predstavlenie n-mernogo prostranstva. II-oe soobshchenie Akademiyam nauk Soyuza SSR $i$ Esst. SSR (manuscript). Archives of the library of Tartu University, Tartu (Estonia), fond 101 , item 5. 
- 1950b. Akademiyam Nauk Est. SSR i Soyuza SSR. Zayavlenie, kasayushcheesya moej raboty pod zaglaviem: Universal'naya geometriya. Naglyadnoe predstavlenie n-mernogo prostranstva. Prilozhenie $k$ nej (manuscript). Archives of the library of Tartu University, Tartu (Estonia), fond 101, item 7 .

- 1950c. Universal'naya matematika i universal'nyj yazyk. Sushchestvennoe $v$ moem issledovanii. Otvet na otzyvy Akademii o moem I-m i II-m soobshcheniyax. III-e soobshchenie Akademii nauk SSSR (manuscript). Archives of the library of Tartu University, Tartu (Estonia), fond 101, item 9.

- 1951-1952. Universal'naya nauka I. Universal'nyj yazyk (manuscript). Archives of the library of Tartu University, Tartu (Estonia), fond 101, item 10.

Linzbach, Jacob 1921. Transcendent algebra. Ideografie matematical. Experiment de un lingue filosofic. Reval: Edition de autor.

- 1931. Idéographie mathématique. Etude du langage philosophique. Algèbre figurée I. Interprétation idéographique de l'équation du $1^{\text {er }}$ degré à une inconnue. Paris: Edition de l'auteur.

Lumiste, Ülo; Võhandu, Leo 2007. Kolmest Eestis loodud tehiskeelest ja nende loojatest. Akadeemia 3: 482-510.

Marr, Nikolaj Yakovlevich 1936[1929]. Pochemu tak trudno stat' lingvistom-teoretikom. In: Marr, Nikolaj Yakovlevich, Izbrannye raboty 2. Leningrad: Gosudarstvennoe sotsial'noèkonomicheskoe izdatel'stvo, 399-426.

Meillet, Antoine 1923. [Review of:] G. de Kolovrat. - Etude sur la vocalisation de la consonne $l$ dans les langues romanes. Paris (Jouve), 1923, in-8, 306 p. Bulletin de la Société de linguistique de Paris 24: 70-72.

- 1924. [Review of:] G. de Kolovrat. - L'inversion du complément direct. L' accent oratoire dans le Roman de Troie. Nice (Imprimerie idéale), 1923, in-8, 137 p. et 8 pages de Suppléments. Bulletin de la Société de linguistique de Paris 25: 111-112.

Mnuhin, Lev Abramovich et al. (eds.) 2008-2010. Rossijskoe zarubezh'e vo Frantsii, 1919-2000. Biograficheskij slovar', v 4 tomah. Moscow: Nauka \& Dom-muzej Mariny Tsvetaevoj.

Moret, Sébastien 2018. Une autre linguistique de 1916: les idées de Ja. Linzbach face à celles de Saussure. In: Joseph, John; Velmezova, Ekaterina (eds.), Le Cours de linguistique générale: réception, diffusion, traduction (Cahiers de l'ILSL, 2018, n 57), 149-163.

Nöth, Winfried 1995. Handbook of Semiotics. Bloomington: Indiana University Press.

Piperski, Aleksandr 2017. Konstruirovanie yazykov ot èsperanto do dotrakijskogo. Moskva: Al'pina non-fikshn.

Pocheptsov, Georgij 1998. Istoriya russkoj semiotiki do i posle 1917 goda. Moskva: Labirint.

Pollock, Ethan 2006. Stalin and the Soviet Science Wars. Princeton: Princeton University Press.

Revzin, Isaak Iossifovich 2009[1965]. O knige Ia. Lintsbaha Printsipy filosofskogo yazyka. Opyt tochnogo yazykoznaniya. In: Lintsbah 2009[1916]: 227-230.

Roero, Clara Silvia; Nervo, Natalie; Armano, Tiziano (a cura di) 2008. L' Archivio Giuseppe Peano (Cd-rom). Comune di Cuneo (Assessorato per la cultura), Università di Torino (Dipartamento di Matematica).

Romeo, Luigi 1979. Lintsbach: A Russian "Saussure"? Ars Semeiotica 2(3): 369-374.

Slaughter, Mary M. 1982. Universal Languages and Scientific Taxonomy in the Seventeenth Century. Cambridge: Cambridge University Press.

Slezkine, Yuri 1996. N. Ia. Marr and the National Origins of Soviet Ethnogenetics. Slavic Review (4): 826-862. 
Stojan, Petro 1929. Bibliografio de Internacia Lingvo. Genève: Bibliografia servo de Universala Esperanto-Asocio.

Tamm, Marek; Kull, Kalevi 2016. Toward a reterritorialization of cultural theory: Estonian theory from Baer via Uexküll to Lotman. History of Human Sciences 29(1): 75-98.

Thomas, Lawrence L. 1957. The Linguistic Theories of N. Ja. Marr. Berkeley: University of California Press.

Tsivian, Yury 1998. Jakob Lintsbach as film semiotician. Elementa 4: 121-129.

- 2014. Cyberspace and its precursors: Lintsbach, Warburg, Eisenstein. In: Kinder, Marsha; McPherson, Tara (eds), Transmedia Frictions: The Digital, the Art, and the Humanities. Berkeley: University of California Press, 80-99.

Velmezova, Ekaterina 2007. Les lois du sens: la sémantique marriste. Bern: Peter Lang.

- 2014. Istoriya lingvistiki v istorii literatury. Moskva: Indrik.

Wahl, Edgar de 1922. Li principies de Occidental. Supplement without page numbers to the journal Kosmoglott 2, March 1922

- 1930. [Review of:] Idéographie mathématique, étude du langage philosophique par Jacob Linzbach. Cosmoglotta 69 (March-April): 31-32.

Waldstein, Maxim 2008. The Soviet Empire of Signs: A History of the Tartu School of Semiotics. Saarbrücken: VDM Verlag Dr. Müller.

\section{Якоб Линцбах о своей жизни и работе}

Эстонский ученый Якоб Линцбах известен, прежде всего, как автор книги “Принципы философского языка: попытка точной лингвистики", изданной в 1916 году на русском языке. В этой книге, как и в других изданных и неопубликованных работах, Линцбах ставит целью создание универсального письменного языка, в котором соединяются математика и изображения. Идеи Линцбаха повлияли на исследователей различных академических областей, таких как семиотика, интерлингвистика, философия, теория кино, информатика и т.д. Однако о жизни самого Линцбаха известно мало. В одной из его рукописей, хранящейся в Тарту, есть глава, которую можно считать автобиографией Линцбаха, она написана карандашом от руки. Этот текст публикуется впервые на английском языке с комментариями.

\section{Jakob Linzbach oma elust ja tegevusest}

Eesti teadlast Jakob Linzbachi tuntakse peamiselt seetõttu, et ta avaldas 1916. aastal venekeelse raamatu pealkirjaga „Filosoofilise keele printsiipidest: täppislingvistika katse”. Selles raamatus, nagu ka muudes tema avaldatud ja avaldamata teostes, püüdles ta kirjaliku universaalkeele loomise poole, milles seguneksid matemaatika ja pildid. Linzbachi ideid on teadvustanud erinevate (teadus)alade esindajad semiootika, interlingvistika, filosoofia, filmiteooria, informaatika jne vallast, ent Linzbachi elu kohta pole kuigi palju avaldatud. Ühes Tartus säilitatavas käsikirjas leidub peatükk, mida võib lugeda autobiograafiaks ning mis Linzbachi enda pliiatsiga kirjutatult pakub teavet tema elu ja tegevuse kohta. Käesolevalt on seda teksti esmakordselt toimetatud, see inglise keelde tõlgitud ning kommentaaridega varustatud. 